Ethiopian Journal of Environmental Studies \& Management 7(1): 59 - 64, 2014

ISSN:1998-0507

doi: http://dx.doi.org/10.4314/ejesm.v7i1.7

Submitted: October 28, 2013

Accepted: January 20, 2014

\title{
EVIDENCE OF GENDER ROLE IN SOYBEAN PRODUCTION: CASE STUDY FROM AGRARIAN COMMUNITIES IN BENUE STATE, NIGERIA
}

\author{
*BALOGUN, K.S. ADISA, R.S., YINUSA, R., ABDULAHAMID, A.T. AND AYINLA, R.A. \\ Department of Agricultural Extension and Rural Development, University of Ilorin PMB 1515, Ilorin, \\ Nigeria
}

\begin{abstract}
The main purpose of this study was to investigate role of gender in soybean production activities in Benue State, Nigeria. Two (2) Local Government Areas (LGAs) were purposively selected from each of the Eastern and Northern Agricultural Zones of the State. Two (2) rural communities were selected from each LGA and finally ten (10) farmers were selected from each community to make a total of eighty (80) farmers that were interviewed. Data were analyzed using simple descriptive statistics such as frequency counts, percentages and mean. Findings revealed that $67.5 \%$ of the respondents were between 30 and 49 years old and $70 \%$ had family size of between 5 and 7 members. Majority had formal education, but was relatively new in soybean production. Women are mostly involved in the tedious farm activities in soybean production such as bush/land clearing, stumping, and tilling. The production needs of men and women were the same in areas like credit/loan facility, supply of improved variety, subsidized farm inputs, availability of land, and pest and disease control. The results of this study provide a strong advocacy for more extension services to be directed towards women farmers so as to encourage their participation in agricultural development programmes in Nigeria.
\end{abstract}

Key words: Gender Role; Soybean Production; Agrarian Communities; Benue State; Nigeria

\section{Introduction}

Gender relates to socially assigned roles and behaviours attributable to men and women. It also refers to the social meaning of biological sex differences (Ogato et al., 2007). Gender roles according to Mollel and Menga (2007) are roles that are played by both men and women and which are not determined by biological factors but by the socio-economic and cultural environment or situation. Development policies and programmes in most developing countries continue to contain assumptions regarding gender roles that place women in stereotyped work such as housewives and secretaries (Bhatta, 2001). Women are considered to be key players in the agricultural sector of most developing countries of the world today as they are seen engaged in a range of productive activities essential to household welfare, agricultural productivity and economic growth (Enete and Amusa, 2010). Millions of women work as farmers and farm workers (Onyemobi, 2000), thereby contributing to national agricultural output and family food security (Brown et al., 2001).

In Nigeria, women play very significant roles in agricultural production, processing and utilization (Nnadozie and Ibe, 2000). However, men have reportedly continued to dominate in crop production activities especially in a crop like soybean which could improve the nutritional conditions of the people (Adisa and Balogun, 2013). Empirical studies highlighted on gender and agricultural production in Africa demonstrate that women do not participate equally with men as opportunities provided by increased agricultural commercialization are usually within the reach of their male counterparts (Horvoka, 2006). The less involvement of women in farming activities has also been attributed to the fact that they are less likely to command the resources required (such as land, credit, or information) required for effective production (Ogunlela and Muktar, 2009). Ajani (2008) reported that women are marginalized in their access to economic, political, and social

*Corresponding Author: Balogun, K.S.

Email: kaypear12006@yahoo.com 
Evidence of Gender Role in Soybean Production: Case Study from Agrarian............... BALOGUN et al.

resources compared to men, rendering them relatively poorer than their male counterparts. $\mathrm{He}$ further identified an unbalanced analysis of women's roles, responsibilities, constraints and opportunities in different activities in relation to those of men.

In Nigeria, the involvement of women in agriculture has attracted greater attention in recent years. A key premise of this study is that male farmers have monopolized agricultural activities especially in the area of crop production and management; hence their female counterparts are following several miles behind (Adisa and Adekunle, 2010). The promotion of sustainable agricultural development in general also requires that the production needs of both men and women farmers are addressed in a way to correct the imbalance existing in task performance and productivity. Thus, to what capacity is the involvement of women in soybean production in the study area becomes a very important issue to examine. The overall purpose of the study was to assess the gender's role participation in soybean production in selected LGAs of Benue State, Nigeria. Specifically, the objectives were;

- To identify the traditional gender related tasks for men and women in soybean production in the study area

- To determine the needs of men and women farmers in soybean production

\section{Methodology}

The study was conducted in four LGAs of Benue State which are Gboko, Guma, Kwande and Vandeikya spread across the Eastern and Northern Agricultural zones of the State, known for their predominance in soybean production (BNARDA, 2000). Two (2) rural communities were purposively selected from each LGA. Thereafter, ten (10) farmers were selected from each of the community to make a total of eighty (80) farmers that were interviewed. The selection was done on the basis of professional advice provided by experienced field officers in the State's Ministry of Agriculture and the Benue State Agricultural and Rural Development Authority (BNARDA). This was due to paucity of current published data on soybean production in the State. A structured questionnaire was used to collect relevant data. This instrument was validated by experts. The study was conducted between March and June 2012.

Data were analyzed using simple descriptive statistics such as frequency counts, percentages and mean. The independent variables were measured as follows: Age (yrs), Marital Status ( single $=1$, married $=2$, separated $=3$, divorced $=4$, widowed=5), and Educational Level (not formally educated $=1$, adult education $=2$, primary education $=3$, secondary education $=4$, tertiary education $=5$ ). The means for production needs were derived from 4-point Likert type scale of Strongly Agree $=4$; Agree $=3$; Disagree $=2$; and Strongly Disagree $=1$. A mean score of 2.50 and above indicated a production need while a mean score lower than 2.50 indicated a non-production need.

\section{Results and Discussion \\ Demographic Characteristics}

Result from field data analysis reveal that $67.5 \%$ of the respondents were within the age range of 30-49 years as shown in Table 1. This implies that they were adults and very active with a high sense of responsibility towards their families (Adisa and Balogun, 2013). Majority $(85 \%)$ was married; $6.25 \%$ divorced; $3.75 \%$ single; and $2.5 \%$ were widowed and separated respectively. This result further suggests that most of them had responsibilities to discharge to their families. Only $8.75 \%$ of the respondents had no education experience. This suggests that the farmers were well informed to understand gender related tasks in relation to soybean production.

Majority $(61.25 \%)$ had 1-10 years experience in growing soybean. The result shows that the farmers were relatively new in soybean farming, and thus would need close attention from the extension system for desired improvement in their production tasks. The length of experience is probably an indicator of a person's commitment to the chosen career (Ejembi et al., 2006). Majority (70\%) had family size of between 5 and 7 which is relatively high. The larger the family size, the larger would be the expected family labour force on the farm. The implication is that the overall production cost would be reduced since little or no wages would be paid. More than half $(53.75 \%)$ of the respondents realized above \#40,000 per season from soybean marketing. This amount is relatively 
high, thus promoting soybean farming as a very lucrative business in the study area.

Table 1: Demographic characteristics of respondents

\begin{tabular}{|c|c|c|}
\hline Variables & Frequency & Percentage (\%) \\
\hline \multicolumn{3}{|l|}{ Age (yrs) } \\
\hline Less than 20 & 08 & 10.0 \\
\hline $20-29$ & 18 & 22.5 \\
\hline $30-39$ & 40 & 50.0 \\
\hline $40-49$ & 14 & 17.5 \\
\hline \multicolumn{3}{|l|}{ Marital Status } \\
\hline Single & 03 & 3.75 \\
\hline Married & 68 & 85.5 \\
\hline Separated & 02 & 2.50 \\
\hline Divorced & 05 & 6.25 \\
\hline Widowed & 02 & 2.50 \\
\hline \multicolumn{3}{|l|}{ Educational Level } \\
\hline Not formally educated & 07 & 8.75 \\
\hline Adult education & 11 & 13.75 \\
\hline Primary education & 10 & 12.50 \\
\hline Secondary education & 47 & 58.75 \\
\hline Tertiary education & 05 & 6.25 \\
\hline \multicolumn{3}{|l|}{ Farming Experience } \\
\hline $1-10$ & 49 & 61.25 \\
\hline $11-20$ & 18 & 22.50 \\
\hline $21-30$ & 08 & 10.00 \\
\hline $31-40$ & 05 & 6.25 \\
\hline \multicolumn{3}{|l|}{ Size of Family } \\
\hline $2-4$ & 17 & 21.25 \\
\hline $5-7$ & 56 & 70.00 \\
\hline $8-10$ & 07 & 8.75 \\
\hline \multicolumn{3}{|c|}{ Soybean Income/Annum (\#) } \\
\hline$<10,000$ & 06 & 7.50 \\
\hline $10,000-19,000$ & 04 & 5.00 \\
\hline $20,000-29,000$ & 15 & 18.75 \\
\hline $30,000-39,000$ & 12 & 15.00 \\
\hline$>40,000$ & 43 & 53.75 \\
\hline
\end{tabular}

\section{Traditional Gender Related Tasks in Soybean} Production

Information about the different traditional tasks carried out by men and women in soybean production was presented in Table 2. It was revealed that men performed tedious tasks such as bush/land clearing (45\%), stumping (38\%), tilling (47\%) and fertilizer application (30\%). This result also agrees with the findings of Ugbokwe and Ufuoku (2005) that men were more involved in land preparation than women in gender division of agricultural tasks as reported in another study conducted in Delta State, Nigeria.

On the other hand, women took the lead in post tillage activities such as planting (85\%), weeding (92\%), harvesting (95\%), processing (97\%) and marketing (88\%). This is also consistent with the traditional gender division of agricultural activities among Tiv farm households in Benue State, where men were historically responsible for heavy tasks including land preparation, while women took over the management of the farm thereafter (Bohannan, 1965; Burfisher and Horestein, 1985).

However, findings from this study show that women are gradually performing tasks that were previously exclusive to men, such as bush/land clearing (30\%), stumping (33\%), tilling (35\%) and fertilizer application (43\%). Uzokwe and Ofuoku (2005) in their study reported that women's involvement in men's tasks in 
agricultural production in Delta State is now becoming very evident. Survey result also complements the findings of Adisa and Okunade (2005) that in the eastern part of Nigeria as a result of rural-urban drift, women have taken over difficult operations from men such as bush clearing, bush burning, staking and tilling, and mould making.

Table 2: Traditional gender related tasks in soybean production

\begin{tabular}{lccc}
\hline Tasks & Men Only (\%) & $\begin{array}{c}\text { Men \& Women } \\
\text { Equally (\%) }\end{array}$ & Women only (\%) \\
Bush/land clearing & & 30 & 25 \\
Stubble burning/stumping & 45 & 33 & 29 \\
Tilling & 38 & 35 & 18 \\
Planting & 47 & 10 & 85 \\
Fertilizer application & 5 & 43 & 27 \\
Weeding & 30 & 6 & 92 \\
Harvesting & 2 & 4 & 95 \\
Processing & 1 & 2 & 97 \\
Marketing & 1 & 7 & 88 \\
\hline
\end{tabular}

\section{Needs of Men and Women in Soybean Production}

Six (6) out of the nine (9) variables examined which could aid production were needed by men (Table 3$)$. These include credit/loan facility $(\chi=$ $3.82)$, supply of improved variety $(\chi=2.53)$, availability of fertilizer $(\chi=2.50)$, subsidized farm inputs $(\chi=2.75)$, availability of land $(\chi=$ $2.81)$, and adequate pest and disease control $(\chi=$ $3.15)$. In contrast, women needed all the nine (9) variables in order to improve performance and obtain better results. This results support the findings of Ogunlela and Mukhtar (2009) that fewer women are generally involved in farming activities because they are unlikely to command the resources required such as land, credit, or information.
However, Table 3 further revealed that both men and women needed six (6) out of the nine (9) variables examined. These were credit/loan facility, supply of improved varieties, availability of fertilizer, subsidized farm inputs, availability of land, and adequate pest and disease control. The significance of these results is that traditional tasks in soybean production would be enhanced if these needs are provided for improved production. Women should be given agricultural extension support; so that they can carry out their production roles as efficient as men. This is also supported by Ogbonna and Okoroafor (2004) as they opine that women would continue to be a positive and leading force in subsistence agricultural production when given the right institutional support and representation.

Table 3: Needs of men and women in soybean production

\begin{tabular}{lll}
\hline Production needs & Men & Mean \\
& $3.82^{*}$ & Women \\
\hline Credit/loan facility & $2.53^{*}$ & $3.10^{*}$ \\
Supply of improved variety & $2.50^{*}$ & $2.75^{*}$ \\
Availability of fertilizer & 2.45 & $2.50^{*}$ \\
Good marketing system & $2.75^{*}$ & $2.82^{*}$ \\
Low cost of farm inputs & 2.50 & $2.50^{*}$ \\
Availability of extension services & $2.81^{*}$ & $2.30^{*}$ \\
Availability of land & 2.31 & $2.65^{*}$ \\
Knowledge of soybean innovations & $3.15^{*}$ & $3.86^{*}$ \\
Pest and disease control & C & $2.69^{*}$ \\
\hline
\end{tabular}

Cut-off score $=2.50 ; 2.50=$ need $;<2.50=$ not a need; $*$ need 


\section{Conclusion and Implication}

Conclusively, the study examined the traditional gender related tasks in soybean production in some farming communities in Benue State, Nigeria. Men and women farmers were jointly involved in production activities such as bush/land clearing, stumping, tilling, and fertilizer application which were previously considered to be exclusive to men. These results suggest that unguided generalizations about gender division of roles in agricultural production should be avoided. The study also revealed that certain production incentives are required to enhance task performance in soybean production. Such needs include credit/loan facility, supply of improved varieties, availability of fertilizer, subsidized farm inputs, availability of land, and adequate pest and disease control. Thus, men and women involved in soybean farming can improve on their respective production tasks when these incentives are available and equitably distributed, thereby invariably increasing output and income.

The following implications for extension services can be drawn from the study findings; The findings revealed that men and women have learnt the value of working together and sharing tasks in soybean production to increase their family income. Hence, the concerned government organizations should give equal attention to men and women in terms of production needs required to boost participation, output and income in soybean farming. Such attention should include incentives like credit/loan facility, subsidized farm inputs, and availability of improved varieties to plant. Finally, it is expected that the findings of this study could be very useful to extension educators especially in places where women make meaningful contributions to agricultural development.

\section{References}

Adisa, R.S. and Adekunle, O.A. (2010). Farmerherdsmen Conflicts: A factor analysis of

Conflict variables among arable crop farmers in north central Nigeria. Journal of Human Ecology, 30:1-9.

Adisa, R.S. and Balogun, K.S. (2013). Impact of Improved Technologies on Small-Scale Soybean Production: Empirical Evidence from Benue State, Nigeria. Pakistan
Journal of Agricultural Sciences, Vol. 50(2), 305-310; 2013.

Adisa, B.O. and Okunade, E.O. (2005). Women in Agriculture and Rural Development In Adedoyin, S.F (ED), Agricultural Extension in Nigeria. Proceeding of Agricultural Extension Society of Nigeria $p$ 69-77.

Ajani, O.I.Y (2008). Gender dimensions of agriculture, poverty, nutrition, and food security in Nigeria. IFPRI Nigeria Strategy Support Program Brief 5, Washington, D.C.: International Food Policy Research Institute.

BNARDA. (2000). Benue State Agricultural and Rural Development Authority, Agricultural Production recommendation for Benue State Extension. Bulletin: 3. Benue State Government, 2002, Diary.

Bhatta, G. (2001). Of Geese and Gander: Mainstreaming Gender in the Context of Sustainable Human Development. Journal of Gender Studies, 10(1): 17-32.

Bohannan, P. (1965). The Tiv of Central Nigeria. In Peoples of Africa, J. (ed.). Holt, Reinehart and Winston Inc., New York, USA. p. 513-546.

Brown, L.R., Feldstein, H., Haadad, L., Pena, C. and Quisumbing, A. (2001). Women as producers, gatekeepers and shock absorbers. In: Per Pinstrup Anderson and Rajul Pandya - Lorch (editors); The Unfinished Agenda - Perspectives on overcoming hunger, poverty and Environmental Degradation DFID Sustainable livelihoods guidance.

Burfisher, M.E. and Horeisten, N.R. (1985). Sex roles in Nigeria Tiv farm household. Women's roles and gender differences in development. Cases for Planners. No. 2. Kumarian Press, West Hartford, Connecticut, USA.

Ejembi, E.P., Omoregbe, F.E. and Ejembi, S.A. (2006). Farmers' assessment of the training and visit extension system in central Nigeria: Evidence from Barkin Ladi, Plateau State. Journal of Social Sciences, 12:201-212.

Enete, A.A. and Amusa, T.A. (2010). Determinants of Women's Contribution to 
Evidence of Gender Role in Soybean Production: Case Study from Agrarian................ BALOGUN et al.

Farming Decisions in Cocoa Based Agro forestry Households in Ekiti State, Nigeria. Field Actions Science Reports, Vol. 4, 2010. Available http//:factsreports.revues.org/396.

Retrieved: January 18, 2012.

Horvoka, A. (2006). The No. 1 Ladies' Poultry Farm: A Feminist Political Ecology of Urban Agriculture in Botswana. Gender, Place and Culture 13(3): 207-255.

Mollel, N.M. and Mtenga, N.A. (2000). Gender Roles in the Household and Farming Systems of Techenzema, MorogoroTanzania. South African Journal of Agricultural Extension, 29: 73-88.

Nnadozie, B. and Ibe, I. (2000). Women in agricultura: Problems and prospects. In: Nwosu A.C., C.U. Nwajiuba and J.A Mbanasor (editors); Agricultural Transformation in Nigeria. Owerri, Imo State, Novelty Industrial Enterprises.

Ogato, G.S., Boon, E.K. and Subramani, J. (2007). Gender Roles in Crop Production and Management Practices: A Case Study of Three Rural Communities in Ambo District, Ethiopia,
Journal of Human Ecology, 27(1): 120.

Ogbonna, K.I. and Okoroafor, E. (2004). "Enhancing the Capacity of Women for Increased Participation in Nigeria Mainstream Agriculture: A Re-designing of Strategies FAMAN Journal, 1(2): 33-48.

Ogunlela, Y.I. and Mukhtar, A.A. (2009). Gender Issues in Agriculture and Rural Development in Nigeria: The Role of Women. Humanity Social Science Journal, 4:19-30.

Onyemobi, F.I. (2000). Towards agricultural revolution and rural development. In: Onyemobi F.I (editor). Women in Agriculture and Rural Development. Towards Agricultural Revolution in Nigeria. Enugu Nigeria, Falude Publishers.

Uzokwe, U.N. and Ofuoku, A.U. (2005). Changes in Gender Division of Agricultural Tasks in Delta State, Nigeria and Implications for Agricultural Extension Services. Extension Farming Systems Journal, 2(1): 91-96. 